\title{
II. Forfatterregister
}

Albeck, Gustav:

Den unge Grundtvig og Norge. . . . . . . . . . . . . . . . .

85 47-66 (96-99)



83 69-86 (99-100)

Grundtvigs rimbreve. . . . . . . . . . . . . .

71 7-30 (127)

Nogle bemærkninger vedrørende en udgave af

Grundtvigs dagbøger. . . . . . . . . . . . . . . . . . . .

Professor Kemp Malone. . . . . . . . . . . . . . .

76 28-41 (74-75)

72 7-9

Albertsen, L. L.:

Grundtvig oversat til tysk Salmetradition.

$7035-40$

Balslev-Clausen, $P$.:

Du, som gaar ud fra den levende Gud.

83 42-68 (98-99)

Bjerre, Svend Erik:

Grundtvig, The Danish Folk High School and the

Developing Countries.

$73160-171$

Borup-Jensen, Th.:

En omstridt Grundtvig-salme og dens forstadier. . .

Bredsdorff, Morten:

Digteren Grundtvig og Goldschmidt. . . . . . . . . .

Grundtvig og Shakespeare. . . . . . . . . . . .

Bøje, Grete:

Injuriesagen mod Grundtvig 1825-1826. . . . . . .

70 56-66 (97)

74 26-50 (91-93)

$6933-46$ (103)

84 34-65 (137)

Egebak, N.:

De Levendes Land. En fortolkning. . . . . . . . . .

70 67-77 (97-98)

Om at tilskrive sig Troens rare klenodie.

71 90-97 (129)

Ehnevid, Th.:

The Dominant Peoples in History according to

Grundtvig and Hegel. . . . . . . . . . . . . .

73 115-127

Elbek, Jorgen:

Deltheden hos Grundtvig efter 1832. . . . . . . . .

Grundtvig i europæisk åndsliv . . . . . . . . . . . . . .

75 33-36 (81-82)

$807-22(94)$

Grundtvigs salmer før Luther. . . . . . . . . . . . . . . . . .

81 30-46 (89)

Mytologen Grundtvig. . . . . . . . . . . . .

83 29-42 (97-98)

Fibiger, Ebbe:

Jesus Kristus - Guds Ord. . . . . . . . . . . . . 
Fibiger, Lise B.:

Grundtvigs væksttanke. . . . . . . . . . .

77-78 213-246

Fibak-Jensen, $H$.:

Grundtvigs erkendelsesteori. . . . . . . . . . .

Forord til

"For sammenhængens skyld". . . . . . . . .

79 29-65 (94-97)

77-78 7-9.

Forord til

Grundtvig-Studier 1984 og 1985 . . . . . . . . . .

$845857-8$

Grundtvig, N.F.S.:

Clara . . . . . . . . . . . . . .

85 9-10

Grenzen der Menschheit. . . . . . . . . . . . .

84 9-22 (135)

$7047-48$

Kirke-Klokken.

$827-16(90)$

Prædiken 31. juli 1825

84 9-22 (135)

Hansen, Uffe:

Guds Ord besunget af Grundtvig. . . . . . . . . . . .

Harbsmeier, Eberhard:

Bibliographie über Grundtvig-Litteratur in nichtskandinavischen Sprachen. . . . . . . . . . .

Harbsmeier, Götz:

Grundtvig and Germany. . . . . . . . . . . . .

Heilesen, Henning:

Et forslag til en grundtvigsk, lærd skole 1833. . . . .

Helweg, Lise:

Til Glæde for Graad. . . . . . . . . . . . . . . . . . .

Herngreen, G. F. W.:

Was könnte Grundtvig heutzutage für reformierte

Christen bedeuten? . . . . . . . . . . . . .

Højer-Pedersen, $K$.:

Grundtvig-Litteratur 1967-1970.

Højlund, Christian:

Håbets mellemrum.

75 39-68 (82-83)

$7652-64$

73 128-138

72 23-39 (70-71)

77-78 247-259

$767-18(74)$

71 107-110

77-78 124-157

Jensen, E. Krebs:

Hjertets gudbilledlighed.

77-78 65-96 (303-304) Jessen, Erland U.:

Grundtvig og H. C. Ørsted . . . . . . . . . . . . Johansen, Steen:

Familiestriden i 1872-73 . . . . . . . . . . . . . .

Grundtvig-manuskripter og grundtvigiana i Det kgl. Bibliotek.

68 33-52 (89-90)

$7240-50$ (71) 
Jorgensen, Aage:

Grundtvig-Litteratur 1971-1973. . . . . . . . . . .

74 76-84

Grundtvig litteratur 1974-1979.

$7977-87$

Jorgensen, Theodor:

Adskillelse og vekselvirkning. . . . . . . . . . .

$8671-83$ (105)

Kallesen, Leif:

Nadverelementerne og billedsynet. . . . . . . . .

77-78 (186)

Larsen, Ejvind:

En naturfilosof efter Grundtvigs hjerte. . . . . . . .

Ludvigsen, $V$. Leth:

Herrens bøn "Fadervor". . . . . . . . . . . . .

73 50-66 (233-234)

77-78 158-185.

Lundgreen-Nielsen, F.:

Grundtvig og "Det litterære Selskab» 1805-1822. . .

"Odin og Saga ". En Grundtvigtekst fra 1810. . . . .

"Rød og hvid i Billedsalen". Grundtvigs mindedigte I. . . . . . . . . . . . . . . . . . . .

"Rød og hvid i Billedsalen". Grundtvigs mindedigte II.

79 10-16 (92)

$8023-60$ (94-95)

81 47-83 (89)

Manniche, Peter:

The International People's College at Elsinore. . . . Michelsen, William:

A century after Grundtvig. . . . . . . . . . . . . .

Det internationale Grundtvig-Seminar 13.-

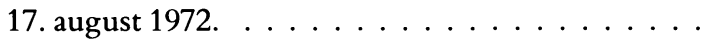

Det moderne menneskes situation og Grundtvigs antropologi.

Grundtvig og hans samtids tænkemåde. . . . . . . .

Leif Garsdal. . . . . . . . . . . . . . . . .

73 152-159

7367

$739-10$

72 9-22 (70)

79 17-28 (92-94)

747

Introduktion til Danne-Virke I .

85 67-78 (99-101)

Introduktion til Danne-Virke II . . . . . . . . . .

86 56-70 (99-102)

N. F. S. Grundtvig: Menneskets grænser (oversættelse) . . . . . . . . . . . . . .

"Hil Dig Frelser og Forsoner" - et nærlæsningsfor-

84 23-34 (135-136)

søg. . . . . . . . . . . . . .

$7251-57(71-72)$

Om Grundtvig og nutiden.

84 80-87 (138-139)

Om Grundtvig som europæer . . . . . . . . . . . . . . . 74 51-53 (73)

Om Grundtvigs tidsopfattelse . . . . . . . . . .

$7642-51(75)$

Om Grundtvigs tænkning og den nyere tids filosofi. . . . . . . . . . . . . . . . $8656-70(99-102)$ 
Redegørelse for indholdet af K. Sølvbjergs afhdl.: "Antropologi og poetik i VK 1814«. . . . . . . . . .

Sin samtids kritiker

Mortensen, Enok:

Den danske salme i Amerika. . . . . . . . . . . . . .

Mortensen, Morten:

74 54-75 (93-94)

Helligånden Guds røst på jord. . . . . . . . . . . . . .

77-78 37-64

Nielsen, Valdemar:

Grundtvigs forhold til Sverige . . . . . . . . . .

Nägele, Horst:

Von einem "Echten Deutsch" und von den "Deutschen Sprachen des Herzens". . . . . . . . . . .

Om "ægte Tydsk" og om de tyske hjertesprog $\mathrm{i}$ Grundtvigs forestillingsverden (dansk resumé). . . .

$7078-88$ (99-100)

$7174-84$

$7185-89$

Prenter, Regin:

Grundtvigs udfordring til moderne theologi. . . . .

$7311-29(219-226)$

Rod, Jakob:

Den lige linie i Grundtvigs religiøse udvikling. . . . Ronne, Karl:

Kirke-Klokken 1845. . . . . . . . . . . . . .

Rordam, Thomas:

The Folk High Schools, their Role and Activity to-

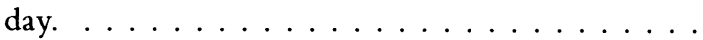

$7011-32(96)$

70 49-55 (96-97)

$73101-114$

Simon, Erica:

Grundtvig et la France . . . . . . . . . . . . . . .

$697-32$

The Grundtvigian "Folkelighed " and Leopold Senghors "Négritude". . . . . . . . . . . . . . . . . .

Skovmand, Roar:

The Rise and Growth of the Danish Folk High



Sølvbjerg, $K$.:

Antropologi og poetik i VK $1814 \ldots \ldots$. . . . . .

Sorensen, Henning:

Troens grund.

82 46-62 (93-94)

$77-7897-12$

Thaning, Kaj:

Den mageløse opdagelses tilblivelse. . . . . . . . . .

81 7-29 (86-88)

Grundtvig, an Introduction . . . . . . . . . . . . . . . . .

$7368-84$

Götz Harbsmeier 1910-1973 . . . . . . . . . . . . 79 7-9 
Hvem var Clara? . . . . . . . . . . . . . . . .

Prædikenen 31. juli 1825 og dens hidtil utrykte slutning. . . . . . . . . . . . . . $8511-46(92-96)$

Toftdahl, Hellmut:

Debatten om Grundtvig og Kierkegaard. . . . . . . .

Grundtvig og Søren Kierkegaard. . . . . . . . . . . .

Lingvistik, systemdigtning og Grundtvig. . . . . . .

Thodberg, Christian:

Den grundtvigske arv. . . . . . . . . . . .

Forord. . . . . . . . . . . . .

77-78 260-292

$77-787$

Grundtvigs skovoplevelse i 1811.

86 11-55 (96-99)

Om Grundtvigs poetik med særligt henblik på den bibelske inspiration. . . . . . . . . . . . .

82 11-55 (96-99)

Var Grundtvigs nadversyn luthersk? . . . . . . . . .

75 7-32 (81) 